\title{
Description of a new species of Coleoptera Melolonthidae Rhizotrogini from Lampedusa Island (Sicily Channel, Italy)
}

\author{
Ignazio Sparacio
}

Via Principe di Paternò 3, 90144 Palermo, Italy; e-mail: edizionidanaus@gmail.com

\begin{abstract}
The populations of Pseudoapterogyna Escalera, 1914 (Coleoptera Melolonthidae Rhizotrogini) from Lampedusa Island (Sicily Channel, Italy) thus far attributed to P. vorax (Marseul, 1878) are revised. A morphological comparison with the North African population of this species (type locality: Algeria Batna) allowed us to attribute the populations of Lampedusa to a new species that is herein described. Observations on the biology and ecology of $P$. maraventanoi $\mathrm{n}$. sp. are provided.
\end{abstract}

KEY WORDS Coleoptera; Melolonthidae; taxonomic; new species.

Received 14.09.2018; accepted 13.10.2018; printed 30.12.2018; published online 07.01.2019

\section{INTRODUCTION}

Biodiversity surveys conducted in the islands of the Sicily Channel (Central Mediterranean, Italy) and North Africa in recent years allowed to obtain new data and to make some taxonomic observations also on populations already known.

In this work, the Pseudoapterogyna Escalera, 1914 populations (Coleoptera Melolonthidae Rhizotrogini) from Lampedusa, known by few records and thus far attributed to P. vorax (Marseul, 1878) (Baraud, 1977, 1985, 1992; Arnone et al., 1995; Carpaneto \& Piattella, 1995; Smetana \& Král, 2006; Ballerio et al., 2010; Sparacio, 2014; Bezděk, 2016), are revised and attributed to a new species which is described below.

ACRONYMS AND ABBREVIATIONS. M. Arnone collection, Palermo, Italy (CMA); A. Ballerio collection, Brescia, Italy (CAB); M. Bellavista collection (CMB); I. Sparacio collection, Palermo, Italy (CIS); Collection of Museum für Naturkunde der Humboldt Universität, Berlin, Germany
(ZMHB); Collection of Museo Civico di Storia Naturale "Giacomo Doria", Genova, Italy (MCSNG); Collection of Museum National d'Histoire Naturelle, Paris, France (MNHN); ex/x: specimen/s. Unless otherwise stated, the collector of the beetles in the field is the owner of the collection.

\section{RESULTS}

\section{Systematics}

Ordo COLEOPTERA Linnaeus, 1758

Familia MELOLONTHIDAE Samouelle, 1819

Subfamilia MELOLONTHINAE Samouelle, 1819

Tribus RHIZOTROGINI Burmeister, 1855

Genus Pseudoapterogyna Escalera, 1914

Pseudoapterogyna maraventanoi $\mathrm{n}$. sp.

Figs. 1, 3, 5, 6, 7

TyPe Material. Holotype male, Italy, Sicily, Lampedusa (Agrigento), 20.XII.2017, leg. G. Mar- 
aventano (CIS); idem, 2 males (CIS); idem, 12.I.2018, 1 male and 2 females (CIS); idem, 18.III.2018, 1 male and 1 female (CIS); idem, 1 male (CAB); idem, 1 male and 1 female (CMB); idem, 1 male (MCSNG). Sicily (Agrigento), Lampedusa, 4.VI.1975, 1 male - Pseudoapterogyna vorax Mars. J. Baraud det., legit B. Massa (CMA); idem, 1 female, 5.VI.1975 (CMA); Sicilia (Agrigento), Isola di Lampedusa, 15.V.1983, 1 female (CIS). Is. Lampedusa, Cala Galera (AG), 1.V.1991, 1 female, R. Poggi (CMA); idem, 2.XII.1992, 1 male(CMA); Lampedusa, 15.IV.2007, 1 female, legit T. La Mantia (CMA).

OTHER EXAMINED MATERIAL. Pseudoapterogyna vorax (Marseul, 1878). Algeria. Apterogyna vorax - Algeria Batna - Museum Paris - Coll. Reiche; Museum Paris - Coll. De Marseul - 2842-90; Rhizotrogus vorax Mars.; Type; Holotype - Apterogyna vorax Marseul, 1878; Holotype - Pseudoapterogyna vorax (Marseul, 1878); Holotype (red label); MNHN EC4185; 1 male (MNHN) (Fig. 8). Tunisia. Tunisi dint., aut.-inv. 1881-2, G. e L. Doria, 2 males (MCSNG) (Figs. 2, 4). Libya. Tripolis Quedenfeldt - Tripolis - S2 - Rhizotrogus Quedenfeldti Brenske, 1 male (ZMHB, only this specimen that matches with Rhizotrogus quedenfeldtii Brenske type, but without any type label). Tripoli - ...; Rhizotr. tripolitanus Fm. - Tripoli; Museum Paris - 1906 - Coll. Léon Fairmaire; Holotype (red label); Type (red label); Holotype - Rhizotrogus tripolitanus Fairmaire, 1884; MNHN EC9678; 1 male (MNHN) (Fig. 9).

Description of holotype. Male. Lenght 16 $\mathrm{mm}$. Shiny, dorsum reddish-brown; sides of pronotum, antennae, palpi, legs, pubescence, and ventral surface yellowish. Head with big, deep and dense punctation on a finely wrinkled surface, a thin, slightly rised transverse carina and two to three irregular, smooth tubercles. Clypeus slightly emarginated at middle of anterior margin. Antennae 10-segmented, club 3-segmented, slightly longer than funicle (lenght funicle/lenght club = 1.15); scape dilated distally, almost as long as the $2^{\circ}$ and $3^{\circ}$ segments together. Pronotum slightly convex, transverse, almost twice as wide as long (lenght pronotum/width pronotum $=1.95)$, sides subrectilinear in the posterior half then narrow and rounded forward, maximum width just before middle, the anterior margin is slightly protruding forward, the posterior margin widely protruding in the back, posterior angles are obtuse and rounded; pronotal sculpturing made of large and shallow punctures irregularly arranged and separated by a surface provided with other very small punctures and with distinct laterobasal depressions; the sides of pronotum bear long and sparse setae, grouped in the central part of the posterior margin; basal bead complete, narrow and punctate. Scutellum triangular with slightly arched sides, and with large, irregular and dense punctures. Elytra subparallel, slightly dilated at apical third, striae wide, well marked and punctuated, interstriae with wide, superficial, irregular punctures, largely confluent on a microreticulated surface; humeral callus visible. Elitral apex with inner apical corner at a right angle. nterior tibiae tridentate, although the basal tooth is hardly visible. Posterior tarsi longer than corresponding tibiae (lenght tarsi/lenght tibiae $=$ 1.8). Posterior tibiae with carina on dorsal side. First posterior tarsomere shorter than the $3^{\circ}$ tarsomere. Claws toothed at the base and with a spine well developed. Pygidium rounded at apex, finely wrinkled, micro-reticulated, with small punctures. Metathoracic wings fully developed. Aedeagus with short and strong parameres with pointed apex.

VARIABILITY. Lenght 14-17 mm. Dorsal surface sometimes blackish, with the sides of the pronotum always yellowish. Females are flightless, have a more convex dorsum and elytra more dilated backward, with dorsal punctation sparse and shorter tarsi; posterior tarsi little longer than posterior tibiae.

Etymology. The specific epithet, a noun in the genitive singular case, honors Giuseppe Maraventano (Lampedusa, Italy) and his naturalistic passion.

Distribution and Biology. This new species is endemic to Lampedusa Island (Sicily Channel, Central Mediterranean Sea, Italy). The specimens of the present study were collected in flight or under stones or by digging (G. Maraventano in verbis), from December to March. Adults active also in May and June (Arnone et al., 1995; Ballerio et al., 2010).

Status And Conservation. The peculiar biology, few populations, and restricted distribution makes $P$. maraventanoi n. sp. as "Vulnerable", ac- 


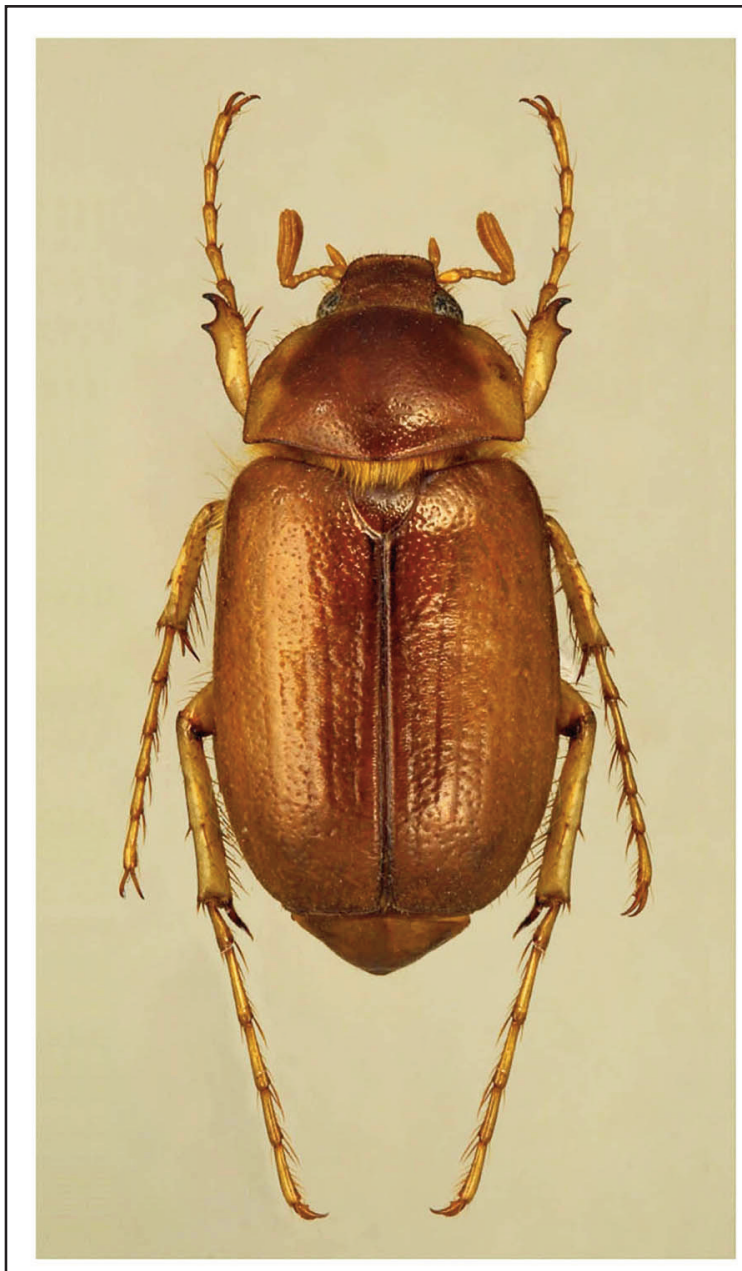

1

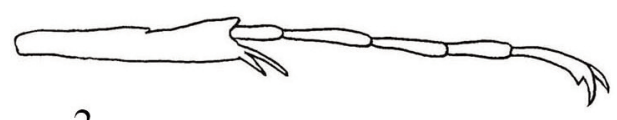

2
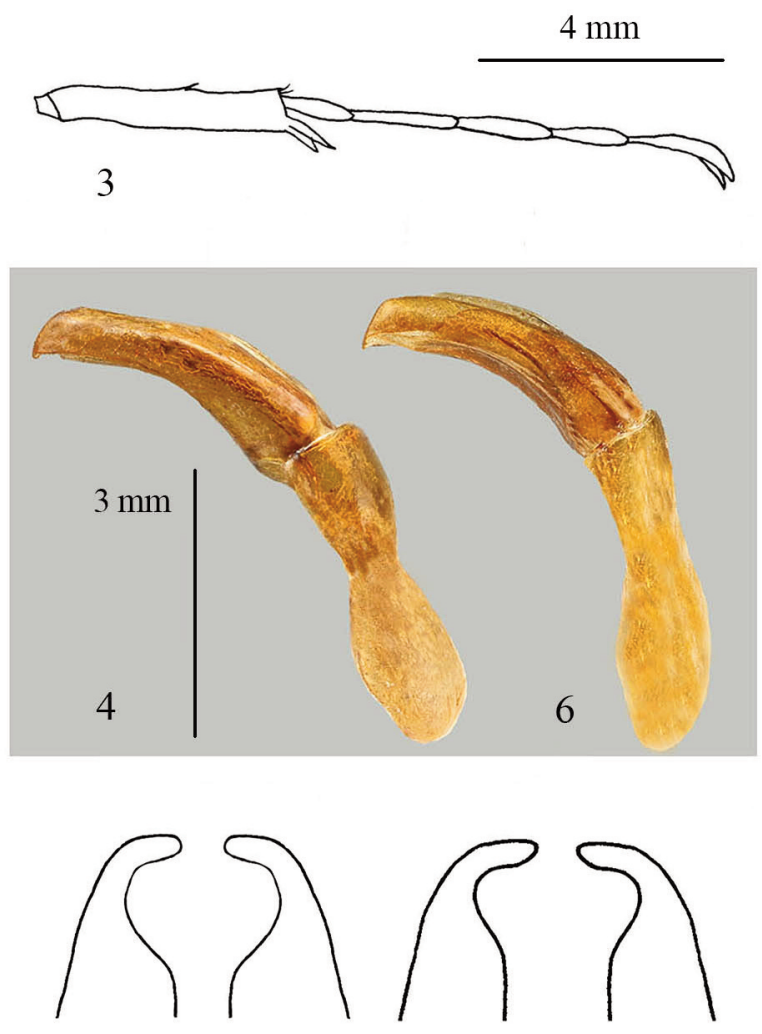

5
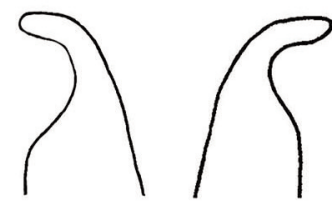

7

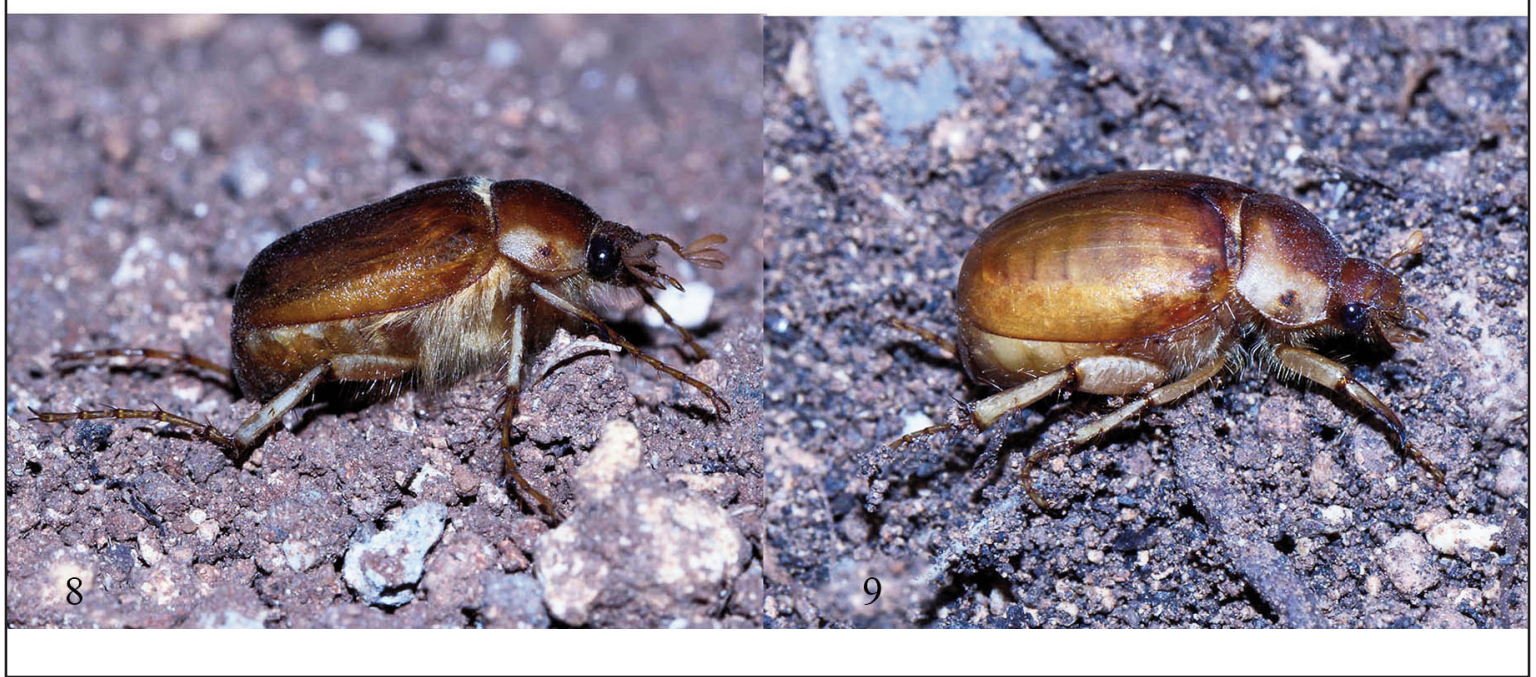

Figure 1. Pseudoapterogyna maraventanoi n. sp. from Lampedusa Island (Sicily Channel, Italy), holotype, lenght $16 \mathrm{~mm}$. Figure 2. Posterior tarsi and tibiae of $P$. vorax from Tunisi dint., Tunisia (MCSNG). Figure 3. Idem of P. maraventanoi $\mathrm{n}$. sp. Figure 4. Aedeagus of $P$. vorax from Tunisi dint., Tunisia (MCSNG). Figure 5. Idem of P. maraventanoi n. sp. Figure 6. Pseudoapterogyna maraventanoi $\mathrm{n}$. sp. from Lampedusa Island, male. Figure 7. Idem, female. 
cording to the Categories and Criteria of the IUCN Red List of Threatened Species (IUCN, 2017).

COMPARATIVE NOTES. This new species appears distinct morphologically from the neighboring North African populations of $P$. vorax, to which it was attributed, as follows:

1. Dorsal surface opaque, reddish-yellow. Pronotum convex, slightly transverse (lenght pronotum/width pronotum $=1.64$ ), surface between the punctures finely wrinkled. Elitrae with maximum width towards the middle. Medial and posterior tarsi longer than the corresponding tibiae (1.65-1.74). Aedeagus elongate with apex pointed...

P. vorax
-. Dorsal surface shiny, reddish-brown with the pronotum sides yellowish. Pronotum slightly convex, very transverse (lenght pronotum/width pronotum $=1.95$ ), surface between the larger punctures covered by very fine simple punctures. Elitrae with maximum width towards in the apical third. Posterior tarsi longer than corresponding tibiae (1.781.85). Aedeagus with parameres shorter and with apex very pointed. P. maraventanoi $\mathrm{n}$. $\mathrm{sp}$.

REMARKS. Recently, we had the opportunity to study a great number of samples thus far attributed to $P$. vorax, that lives in Lampedusa, mentioned in few specimens (Baraud, 1977; Arnone et al., 1995; Sparacio, 2014). This allowed us to distinguish $P$. maraventanoi $\mathrm{n}$. sp. of Lampedusa from $P$. vorax of

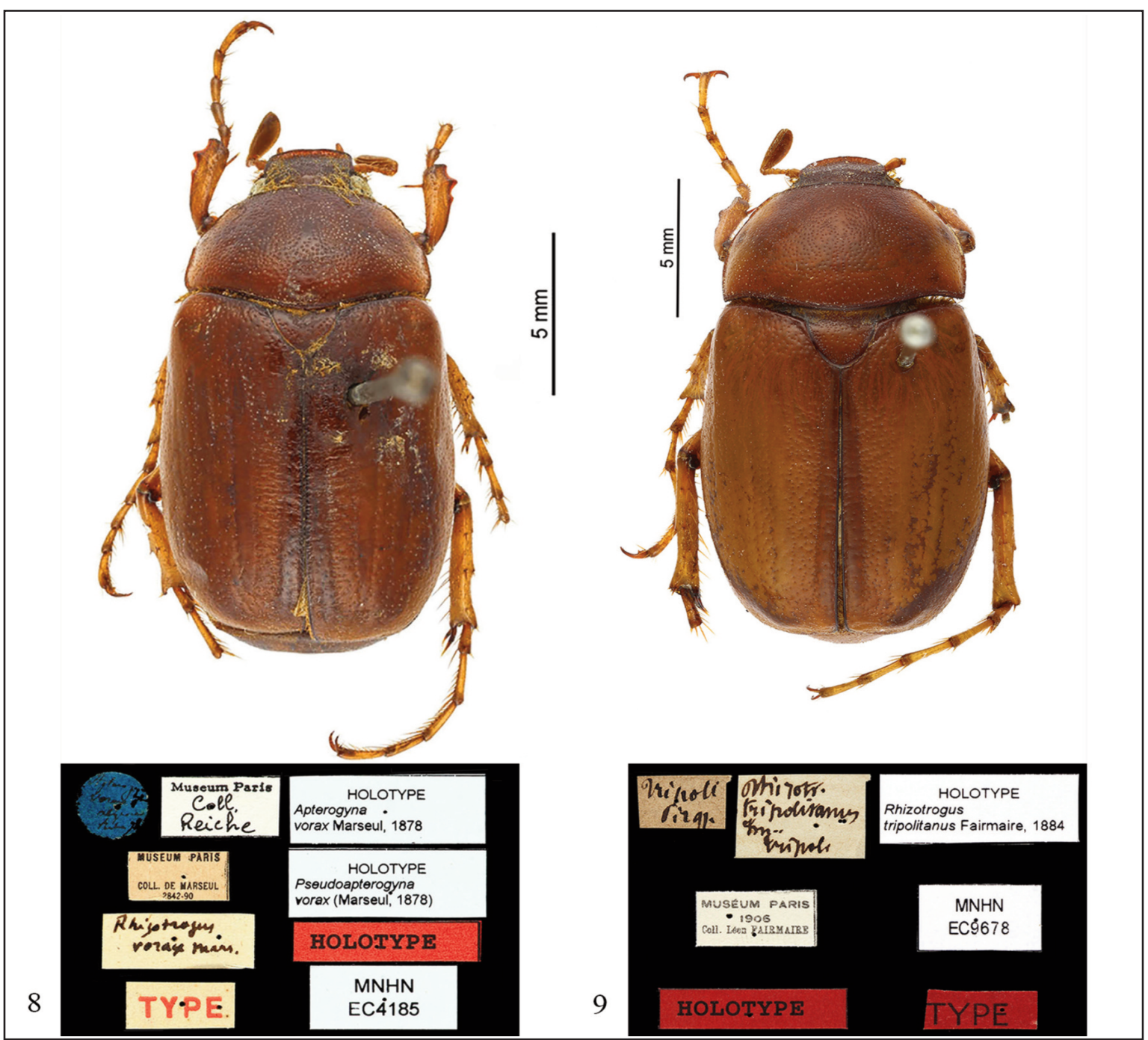

Figure 8. "Rhizotrogus" vorax Marseul, 1878, holotype, Algeria, Batna (MNHN). Figure 9. "Rhizotrogus" tripolitanus Fairmaire, 1884, holotype, Tripoli, Libya (MNHN). 
North Africa, of which we have also studied the typical material (Algeria, Batna) and the types of the two synonym recognized for this species: P. tripolitanus Fairmaire, 1884 (Libya, Tripoli) e P. quedenfeldti Brenske, 1890 (Libya, Tripolis, Kédna), very similar to other North-African populations of $P$. vorax.

Pseudoapterogyna vorax was described for Batna in Algeria (Marseul, 1878) and it is widespread from Morocco to Libya (Baraud, 1977, 1985, 1992; Smetana \& Král, 2006; Bezděk, 2016). Baraud (1977) was the first to report the occurrence of this species in Lampedusa (on specimens collected from B. Massa, 4/5.VI.1975), and he stated (Baraud, 1977) that, despite the wide range of this species and the fact that $P$. vorax is "assez variable", the specimens he had examined from Lampedusa "semblent peu different de la forme nominative (Algerie)".

This species is reported for Lampedusa in all the recent relevant literature (Baraud, 1985, 1992; Carpaneto \& Piattella, 1995; Ballerio et al., 2010; Sparacio, 2014; Bezděk, 2016). Arnone et al. (1995) provided new collection data on $P$. vorax in Lampedusa (Cala Galera), while Lo Cascio (2004) and Smetana \& Král (2006) reported this species also for Lampione, a very small island located near Lampedusa.

Now, all the reports of $P$. vorax of Lampedusa Island will be reported as of $P$. maraventanoi $\mathrm{n}$. sp.

Finally, I have chosen to keep this new species in the genus Pseudoapterogyna (see also Sparacio, 2014) even if I am aware of Coca-Abia's molecular research (2003), which suggests a synonymy of Pseudoapterogyna with Geotrogus GuérinMéneville, 1842. Her research, however, must be regarded as preliminary, being based on the examination of only three species out of the over 50 taxa involved (Baraud, 1986; Smetana \& Král, 2006; Bezděk, 2016; Miessen et al., 2017).

A broader molecular genetic work, to confirm these preliminary data, is therefore needed in order to confirm Coca-Abia's preliminary results.

\section{ACKNOWLEDGEMENTS}

I am grateful to Marcello Arnone (Palermo, Italy), Alberto Ballerio (Brescia, Italy), Marcello Romano (Capaci, Italy), Roberto Poggi (Museo
Civico di Storia Naturale, Genova, Italy), Antoine Mantilleri (Museum National d'Histoire Naturelle, Paris, France), and Joachim Willers (Museum für Naturkunde der Humboldt Universität, Berlin, Germany). Moreover, I am grateful to the staff of Legambiente of Lampedusa (Italy) and to Tommaso La Mantia (University of Palermo) for their support in these researchs.

\section{REFERENCES}

Arnone M., 2010. Quinto contributo alla revisione della collezione coleotterologica di Enrico Ragusa: Scarabaeoidea. Il Naturalista siciliano, 34: 61-172.

Arnone M., Carpaneto G.M. \& Piattella E., 1995. Arthropoda di Lampedusa, Linosa e Pantelleria. Coleoptera Scarabaeoidea. Il Naturalista siciliano, 19 (Suppl.): 447-468.

Ballerio A., Rey A., Uliana M., Rastelli M., Rastelli S., Romano M. \& Colacurcio L., 2010. Piccole Faune. Coleotteri Scarabeoidei d'Italia. DVD. M. Serra Tarantola ed., Brescia, 1-13 + dvd pp.

Baraud J., 1977. Faune de 1'Europe occidentale: Belgique, France, Grand-Bretagne, Italie, Peninsule iberique. IV. Coléoptères Scarabaeoidea. Nouvelle Revue d'Entomologie, Toulouse, 7 (suppl.): 1-352.

Baraud J., 1985. Encyclopédie Entomologique XLVI. Coléoptères Scarabaeoidea. Faune du Nord de 1' Afrique du Maroc au Sinaï. Édition Lechevalier, Paris, 1-651.

Baraud J., 1992. Coléoptères Scarabaeoidea d'Europe Faune de France: France et régions limitrophes, 78. Société Linnéenne de Lyon: 856 pp.

Bezděk A., 2016. Cetoniinae. In: Löbl I. \& Löbl D. (Eds.), Catalogue of Palaearctic Coleoptera. Vol. 3. Scarabaeoidea - Scirtoidea - Dascilloidea Buprestoidea - Byrrhoidea. Revised and updated edition. Brill: Leiden, Boston, pp. 367-412.

Carpaneto G.M. \& Piattella E., 1995. Coleoptera Polyphaga V (Lucanoidea, Scarabaeoidea). In: Minelli A., Ruffo S. \& La Posta S. (Eds.), Checklist delle specie della fauna italiana. Calderini, Bologna, 50: $1-18$.

Carpaneto G.M., Audiso P., Baviera C. \& Sparacio I., 2014. Famiglia Scarabaeidae (inclusi Cetoniinae e Dynastinae). In: Audiso P., Baviera C., Carpaneto G.M., Biscaccianti A.B., Battistoni A., Teofili C. \& Rondinini C. (compilatori), Lista Rossa IUCN dei Coleotteri saproxilici italiani. Comitato Italiano IUCN e Ministero dell'Ambiente e della Tutela del Territorio e del Mare, Roma, 133 pp.

Coca-Abia M., 2003. Phylogenetic relationships and distribution of the Rhizotrogini (Coleoptera, Scarabaei- 
dae, Melolonthinae) in the West Mediterranean. Graellsia, 59: 443-455.

IUCN, 2017. The IUCN Red List of Threatened Species. Version 2017-3. http://www.iucnredlist.org (Last access: 05.VIII.2018).

Lo Cascio P., 2004. Nuovi dati sui Coleotteri di Lampione (Canale di Sicilia). Il Naturalista siciliano, 28: 1229-1231.

Marseul S.-A. de, 1878. Nouvelles et faits divers de l'Abeille. Mélanges (suite). Deuxième série. L'Abeille, Journal d'Entomologie, 16: 63-68.

Miessen G. \& Benyahia Y. \& Brustel H., 2017. Une nouvelle espèce de Geotrogus Guérin-Méneville pour la faune du Maroc et catalogue actualisé des espèces du genre (Coleoptera: Scarabaeoidea: Melolonthidae: Rhizotrogini). Bulletin de la Société Royale Belge d'Entomologie, 153: 131-135.

Smetana A. \& Král D., 2006. Rhizotrogini. Pp. 207-228. In: Löbl I. \& Smetana A. (Eds.), Catalogue of Palaearctic Coleoptera. Vol. 3. Scarabaeoidea, Scirtoidea, Dascilloidea, Buprestoidea, Byrrhoidea. Apollo Books, Stenstrup, 690 pp.

Sparacio I., 1995. Coleotteri di Sicilia. I. L'Epos Società Editrice, Palermo, 238 pp.

Sparacio I., 2014. Taxonomic notes on the genus Pseudoapterogyna Escalera, 1914 (Coleoptera Scarabaeoidea Melolonthidae) in Sicily. Biodiversity Journal, 5: 359-366. 